\title{
The Centenary of the Japanese Dermatological Association
}

\author{
Karl Holubar ${ }^{a}$ Jean-Hilaire Saurat ${ }^{b}$ \\ aInstitut für Geschichte der Medizin der Universität Wien, Österreich; \\ bHôpital Cantonal, Clinique Dermatologique, Genève, Suisse
}

Japan was the first country outside the Euro-American sphere which implanted the teachings and techniques of the famous schools of dermatology of 19th century Europe onto her own soil. Kentaro Murata (1862-1892) had been in Europe before his short-lived professorship (1890-1892). After his untimely demise, Keizo Dohi (Ishiwata) (1866-1931) trained first under Kaposi in Vienna and thereafter completed his education in other prestigious continental centers. He became the father of modern dermatology in Japan, figurehead of the discipline in East Asia and founder of the Dermatology Society of Japan as it was called at the beginning. The Dohi Atlas (1903-1910) [1] and his textbook [2], which saw three editions already before World War I (1910, 1911, 1914, and the moulages produced in Tokyo by Dohi and his pupils in the best tradition of Jules Baretta in Paris and Carl Henning in Vienna (where Dohi learned the technique) are proof of this European heritage and roots. The Dohi Memorial Lectureship established in 1957, in Tokyo, is intended to perpetuate the memory of the master, Stephan Rothman was the first Dohi Lecturer in 1958.

The foundation of the Dermatology Society of Japan (today the Japanese Dermatological Association, JDA) was prepared by some 50 dermatologists assembled by Keizo Dohi on December 15, 1900, at the Ueno Seiyoken restaurant in Tokyo. On February 3, 1901, the first regular meeting of the society was held at the lecture room of Legal Medicine at the University of Tokyo, and on April 8-9, 1901, the first congress took place in Tokyo [3]. The latter date may be seen as the beginning of the scientific activity of the society and will be marked these days with a centennial ceremony and meeting in Tokyo.

\begin{tabular}{ll}
\hline KARGER & ( ) 2001 S. Karger AG, Basel \\
1018-8665/01/2022-0085\$17.50/0 \\
$\begin{array}{l}\text { Fax +4161306 1234 } \\
\begin{array}{l}\text { E-Mail karger@karger.ch } \\
\text { www.karger.com }\end{array}\end{array}$ & $\begin{array}{l}\text { Accessible online at: } \\
\text { www.karger.com/journals/drm }\end{array}$
\end{tabular}

Fig. 1. By an irony of history, the original lecture hall of the HebraKaposi department of dermatology at the Old Vienna General Hospital (background) is occupied today by the Department of Japanology of Vienna University, and a traditional Japanese stone garden is right before the entrance (foreground). 'Und in Wien lebt Dohis Andenken weiter, an der Stelle seines ersten Wirkens.'

The JDA had 163 members in 1901, currently there are 9,071 altogether, including 4,150 qualified specialists, 1,500 resident members, 441 contributing members, 73 honorary members and 54 foreign honorary members ( $\mathrm{T}$. Nishikawa, personal commun.). With more than 4,000 qualified dermatologists, the JDA appears to be the second biggest dermatological society after the American Academy of Dermatology and well ahead of both the French and German Societies with about 2,500 members each. Over the years, JDA members significantly contributed to the advancement of our specialty [4]. Japanese \begin{tabular}{ll}
\hline K. Holubar, MD, FRCP, Prof. and Chairman & J.-H. Saurat, MD, Prof. and Chairman \\
Institute for the History of Medicine & Clinique \& Policlinique de Dermatologie \\
Währinger Strasse 25 & Hôpital cantonal universitaire \\
A-1090 Vienna (Austria) & CH-1211 Genève 4 (Switzerland) \\
Tel. +43 1 4277 63 401, Fax +431427796 34 & Tel. +41 22 37294 22, Fax +41 22 3729460
\end{tabular} 
dermatologists described more than 30 new skin diseases [5-7]. Initially, these conditions described in Japan were thought to be characteristic of Mongoloid peoples; however, the dissemination of knowledge disclosed that diseases first described in Japanese turned out to be seen also in other clines of man. Nevus of Ota, nevus of Ito, incontinentia pigmenti achromians, Kimura's disease, eosinophilic pustular folliculitis (Ofuji), papuloerythroderma (Ofuji) and prurigo pigmentosa (Nagashima) are paradigmatic in this respect, among many others [8, 9].

The foundation of the Japanese Society of Investigative Dermatology (JSID) in 1975 paralleled that of the SID in the USA, in 1938, and of the ESDR in Europe, in 1973, in all three locations supplementing the activities of the mother societies in the field, with basic research in dermatology. In major journals of our specialty it is not easy to find an issue without a paper from Japan. The pages of the top journal, the Journal of Investigative Dermatology, offer ample proof, and the programs of the Three-Continental Meetings of the research societies do the like. Many distinguished Japanese colleagues are leaders in important areas of dermatology. At present, a Japanese professor is secretary of the International Committee of Dermatology, a fact which illustrates the prestige Japanese dermatology has won among its peers all over the world.

Our journal has used for years the skills of Japanese colleagues in the peer review process, and we are proud to count on the regular help of Japanese associate editors and advisory board members.

Dohi has planted a tree 100 years ago. It has grown and flourished.

\section{References}

1 Dohi K: Atlas der Hautkrankheiten. Tokyo, 1903-1910 (50 color pictures, folio).

2 Dohi K: Lehrbuch der Dermatologie, ed 3. Tokyo, Asakaya, 1914.

3 Yasuda T, Nagatoya Y: The History of Dermatology in Japan. Brochure distributed at the International Congress of Dermatology, Tokyo, 1982, edited by the authors.

4 Fukuyama K, Yasuda T: Outstanding contributions by Japanese dermatologists. J Am Acad Dermatol 1982;6:173-178.
5 Teraki Y, Nishikawa T: Skin diseases first described in Japan. J Dermatol 1994;21:139_ 151.

6 Teraki Y, Nishikawa T: In Japan beschriebene Dermatosen. Teil 1 und 2. Hautarzt 1994;45: 125-131, 197-205.

7 Imamura S: Skin diseases first described in Japan, Clin Dermatol 1999;17:117-126.

8 Holubar K, Fatovic-Ferencic S: 100 years of Japanese dermatology: A perspective from abroad. J Dermatol Sci, in press.

9 Holubar K, Fatovic-Ferencic S: Austria and Japan: Early relations in dermatology. Jpn J Dermatol, in press. 